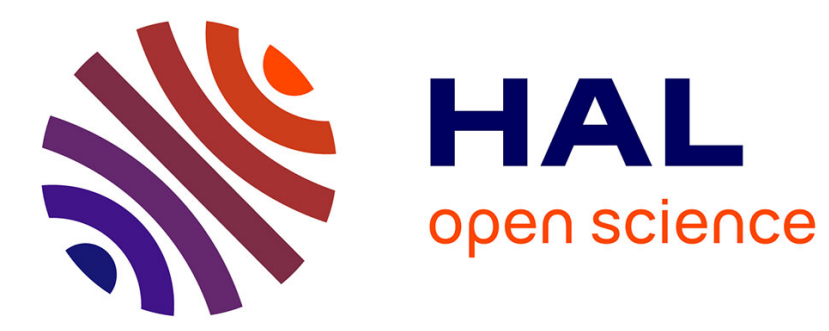

\title{
Phytotoxicity and fertilising potential of olive mill wastewaters for maize cultivation
}

\author{
Siham Hanifi, Ismaïl El Hadrami
}

\section{To cite this version:}

Siham Hanifi, Ismail El Hadrami. Phytotoxicity and fertilising potential of olive mill wastewaters for maize cultivation. Agronomy for Sustainable Development, 2008, 28 (2), pp.313-319. hal-00886389

\section{HAL Id: hal-00886389 \\ https://hal.science/hal-00886389}

Submitted on 1 Jan 2008

HAL is a multi-disciplinary open access archive for the deposit and dissemination of scientific research documents, whether they are published or not. The documents may come from teaching and research institutions in France or abroad, or from public or private research centers.
L'archive ouverte pluridisciplinaire HAL, est destinée au dépôt et à la diffusion de documents scientifiques de niveau recherche, publiés ou non, émanant des établissements d'enseignement et de recherche français ou étrangers, des laboratoires publics ou privés. 


\title{
Phytotoxicity and fertilising potential of olive mill wastewaters for maize cultivation
}

\author{
Siham HANIFI, Ismaïl El HADRAMI* \\ Laboratoire de Biotechnologies, Protection et Valorisation des Ressources Végétales, Département de Biologie, Faculté des Sciences-Semlalia, BP 2390, \\ 40000 Marrakech, Maroc
}

(Accepted 18 September 2007)

\begin{abstract}
The use of organic wastes as agricultural amendment is an effective strategy to regenerate degraded soils and represents an economical alternative that provides a local source of fertiliser. Olive mill wastewaters are widely known for their fertilising value. However, they can still not be recommended as a safe practice because of their potential ecological risks. Here, the effect of olive mill wastewaters on maize is investigated. Olive mill wastewater samples were collected in semi-modern and traditional mills of the Marrakech area, Morocco. Samples were analysed for $\mathrm{pH}$, electrical conductivity and total phenolic content. Major phenolic compounds were identified and quantified. Phytotoxicity was assayed in the laboratory using maize seedlings, and under field conditions. Field fertilisation was conducted through land application accompanied or not by foliar spray according to a fractionated application mode. Our results show a high variability in physicochemical characteristics of wastewaters, notably for phenolic profiles. Variable toxicity levels were also attributed to each sample according to its salinity and phenolic load. Under field conditions, a 9\% reduction of seedling emergence was observed in olive mill wastewater-pre-treated soil as compared with the control. However, olive mill wastewater-fertilised plots showed a net improvement in plant height of $10-11 \%$ compared with the control. A yield improvement reached $28 \%$ over that of the control when the plants were amended both by land application and foliar spray. These results show that the large variability in olive mill wastewaters composition constitutes a major limiting factor for their re-use in agricultural systems. Olive mill wastewaters can be used as a safe agronomic amendment provided the application is moderate and progressive and critical development stages are avoided, notably the preliminary development stages. Foliar fertilisation using olive mill wastewaters is also revealed to be a promising way to manage these effluents.
\end{abstract}

olive mill wastewaters / water re-use / phenolics / phytotoxicity / foliar fertilisation / maize

\section{INTRODUCTION}

In the Mediterranean basin, particularly in the southern bank, the majority of soils are of poor quality due to organic matter deficiency and water scarceness. In such a context, recycling organic effluents, notably olive mill wastewaters, may constitute a doubly suitable method to reclaim soil fertility and preserve water.

However, the investigation of a judicious use of olive mill wastewaters as agronomical input requires the control of their potential hazards. While several studies reported on the benefits of olive mill wastewaters for both soil and crops (Tomati et al., 1996; Mellouli et al., 1998; Ben Rouina et al., 1999), many other authors highlighted the detrimental effects of these effluents, including their phytotoxicity (El Hadrami et al., 2004; Mekki et al., 2006) and their effect on soil (Zenjari and Nejmeddine 2001; Piotrowska et al., 2006). These contradictions can be explained by the interaction between opposite effects that counteract each other. For instance, phenolics, a major olive mill wastewater component, possess both stimulating and inhibiting effects (An et al., 2001). Inconsistent effects of olive mill wastewaters on germination were also attributed to a dose effect (Casa et al., 2003; D'Annibale et al., 2004). On the

*Corresponding author: hadrami@ucam.ac.ma other hand, the impact of organic wastes on crops was shown to be different depending on the spreading time (Rashid and Voroney 2004). This seems to be particularly dependent on the mineralisation time, which controls nutrients' bio-availability (Eghball et al., 2004).

These statements point to the requirement of a novel mode of recycling olive mill wastewaters. This novel mode should conciliate the valorisation of their fertilising potential and the reduction of their potential toxic effects through appropriate storage and a fractionated application. In this respect, our investigation intends to study (i) the phytotoxicity of olive mill wastewaters in relation to their physicochemical properties and (ii) the suitability of olive mill wastewater amendment by a fractionated application to the soil as well as foliar fertilisation.

\section{MATERIALS AND METHODS}

\subsection{Olive mill wastewater sampling}

Olive mill wastewater samples were collected from traditional and modern mills in three sites in the Marrakech region (Morocco) and named S1, S2, S3, S4 and S5. S1 and S2 
were collected at the Tahnaout site in a traditional and a semimodern mill, respectively. S3 and S4 were collected from the Loudaya site in February and April, respectively, in order to evaluate the intra-mill variability.

\subsection{Olive mill wastewater physicochemical analyses}

The physicochemical analyses were conducted on three to five samples of each olive mill wastewater stock. $\mathrm{pH}$ and electrical conductivity $\left(\mathrm{mS} \mathrm{cm}^{-1}\right)$ were measured using a pH-meter (WTW-pH meter, 330/set-1) and conductivimeter (WTW-Conductivimeter, F318/set), respectively. Hydrosoluble phenolic compounds of each olive mill wastewater sample were extracted three times with an equal volume of ethyl acetate. After evaporation of the organic phase, the residue was suspended in pure methanol and kept at $-20{ }^{\circ} \mathrm{C}$ until used. Total contents of phenolic compounds were estimated using Folin-Ciocalteu reagent (Sigma, France). Results are expressed in $\mu \mathrm{g}$ eq. $(+)$-catechin by reference to a standard scale established in the same conditions using (+)-catechin ethanolic solution. Phenolic extracts were also analysed by HighPerformance Liquid Chromatography using a Waters 600E HPLC equipped with a Waters 990 photodiode array detector and Millipore software for data analysis. An efficient gradient of acetonitrile-o-phosphoric acidified bi-distilled water ( $\mathrm{pH}=2.6$ ) was used with an Interchrom $\mathrm{C} 18,5 \mu \mathrm{m}$ reversedphase column. Three wavelengths $(280,320$ and $350 \mathrm{~nm})$ were used during the elution, and data collection and integration were performed with the Millipore software. Phenolics were identified on the basis of their retention times and their spectra in comparison with standards. When necessary, co-injection and elution with standards were used to confirm the identity of some compounds.

\subsection{Laboratory phytotoxicity assessment}

The experiment was designed in three blocks with three replicates per block. Seeds of a local variety of maize (Zea mays) were used. Germination was first performed with different concentrations ranging from 0 to $75 \%(\% \mathrm{v})$ of olive mill wastewaters. The concentration of $12.5 \%(\% \mathrm{v})$ diluted samples was then selected for the following experiment, as it did not affect the germination rates. Ten seeds per Petri dish were incubated at $25^{\circ} \mathrm{C}$ in the dark. The germination rate, expressed as the percentage of germinated seeds, was calculated for each treatment. Radicle and coleoptile elongation were recorded after 5 days. Fresh and dry weights were recorded after eight days.

\subsection{Field assays}

In order to evaluate the interference between olive mill wastewaters' effects and soil conditions, agronomic tests were performed under field conditions at Cadi Ayyad University. The climate of the area is semi-arid to arid, characterised by a dry season from April to October and a humid season from November to March, with an average annual rainfall of $240 \mathrm{~mm}$. The annual average temperature is $18^{\circ} \mathrm{C}$ with a maximum of $38^{\circ} \mathrm{C}$ in August and a minimum of $3.5^{\circ} \mathrm{C}$ in January. Two years' experiments were conducted in $3 \mathrm{~m} \times 2 \mathrm{~m}$ plots. In the first year, fertilisation was carried out at a rate of about $40 \mathrm{~m}^{3}$.ha ${ }^{-1}$ crude olive mill wastewaters. A plot without olive mill wastewaters was used as a control. The plots were tilled and left empty until the following year. A second maize cultivation was achieved in the same plots by sowing 120 seeds of a local variety per plot. Seedling emergence rates were recorded. During the experiment, fertilisation was achieved by crude olive mill wastewater soil application at a rate of $30 \mathrm{~m}^{3} \cdot \mathrm{ha}^{-1}$ coupled or not with a foliar spray of filtrated olive mill wastewaters. The applied amount of olive mill wastewaters was fractionated into several doses applied once weekly to gradually reach the final expected concentration. Plant height as well as physiological parameters, notably phenolic and peroxidase activities, were recorded. The yield, estimated by the weight of kernels and the weight of 100 seeds, was evaluated after harvest.

\subsection{Phenolic and peroxidase analyses}

Roots were ground at $4{ }^{\circ} \mathrm{C}$ with $80 \%$ methanol (\%v). Total phenolic levels were determined using the Folin-Ciocalteu method. Results are expressed in mg eq. (+)-catechin by reference to a standard scale established in the same conditions using (+)-catechin solution. Peroxidase activity assays were performed by homogenising root tissues with Tris-maleate buffer (pH 6.5) containing $0.5 \%$ triton $(\% \mathrm{v})$. Aliquots of the supernatant were assayed for peroxidase activity after addition of $10 \% \mathrm{H}_{2} \mathrm{O}_{2}(\% \mathrm{v})$ and gaïacol at $28{ }^{\circ} \mathrm{C}$. The absorbance was evaluated at $470 \mathrm{~nm}$ after launching the reaction by adding $\mathrm{H}_{2} \mathrm{O}_{2}$. Phenolic extracts were analysed by HPLC as described above.

\subsection{Statistical analysis}

Olive mill wastewater physicochemical analyses were conducted on three to five samples of each olive mill wastewater stock. Phytotoxicity assessment was carried out in triplicate and the experiment was repeated three times. Seedling growth measurement was made on each one of the ten seedlings used per Petri dish. Biomass production was assessed three times on sub-samples consisting of five seedlings. Field growth evaluation was achieved on 20-30 plants per treatment. Data was analysed using one-way analysis of variance $(P<0.05)$ using Statistica software (StatSoft Inc. Ed' 99).

\section{RESULTS AND DISCUSSION}

\subsection{Physicochemical characterisation of olive mill wastewaters}

Olive mill wastewater (OMW) application to agricultural soils constitutes a practical strategy to valorise their fertilising 
Table I. Main physicochemical characteristics of the tested olive mill wastewater samples (S1, S2, S3, S4 and S5). Different letters within the same column mean significant difference recorded at $P<0.05$.

\begin{tabular}{lccc}
\hline $\begin{array}{l}\text { Olive mill waste waters' } \\
\text { samples }\end{array}$ & $\mathrm{pH}$ & Electrical conductivity $\left(\mathrm{mS} \mathrm{cm}^{-1}\right)$ & Phenolics $\left(\mathrm{g} \mathrm{L}^{-1}\right)$ \\
\hline S1 & $4.84 \pm 0.01^{\mathrm{b}}$ & $39.92 \pm 0.04^{\mathrm{c}}$ & $3.34 \pm 0.4^{\mathrm{c}}$ \\
S2 & $4.63 \pm 0.03^{\mathrm{d}}$ & $11.24 \pm 0.17^{\mathrm{e}}$ & $2.96 \pm 0.04^{\mathrm{c}}$ \\
S3 & $4.88 \pm 0.02^{\mathrm{a}}$ & $83.3 \pm 0.20^{\mathrm{a}}$ & $6.08 \pm 0.43^{\mathrm{a}}$ \\
S4 & $4.81 \pm 0.03^{\mathrm{c}}$ & $71.22 \pm 0.13^{\mathrm{b}}$ & $6.09 \pm 0.18^{\mathrm{a}}$ \\
S5 & $4.85 \pm 0.01^{\mathrm{b}}$ & $30.36 \pm 0.05^{\mathrm{d}}$ & $5.8 \pm 0.84^{\mathrm{b}}$ \\
\hline
\end{tabular}

Table II. Phenolic compound amounts of several samples of olive mill wastewaters (S1, S2, S3, S4 and S5) in mg eq. catechol L ${ }^{-1}$ collected in the Marrakech Region (Morroco).

\begin{tabular}{lccccc}
\hline & S1 & S2 & S3 & S4 & S5 \\
\hline Tyrosol & 0.00 & 1375.71 & 4111.88 & 3468.61 & 3410.19 \\
Catechol & 1376.66 & 216.29 & 408.85 & 534.37 & 675.84 \\
Caffeic acid & 0.00 & 0.00 & 967.81 & 0.00 & 0.00 \\
-coumaric acid & 0.00 & 0.00 & 341.48 & 0.00 & 0.00 \\
Unidentified hydroxycinnamic derivative $\left(^{11}\right)$ & 0.00 & 0.00 & Traces & 226.06 & 0.00 \\
Unidentified flavonoid $\left({ }^{7}\right)$ & 0.00 & 0.00 & 51.16 & 0.00 & 0.00 \\
Luteolin & 0.00 & 204.93 & 0.00 & 0.00 & 0.00 \\
Luteolin derivative & 81.02 & 0.00 & 91.66 & 56.26 & 134.98 \\
Oleuropein derivative & 311.37 & 383.66 & 476.88 & 664.56 & 502.51 \\
\hline
\end{tabular}

value and to resolve the problem of their disposal. However, data concerning their agricultural recycling is contrasting and further studies are needed to ensure a safe agronomic re-use of these effluents. In this sense, we propose to study olive mill wastewaters' effect on maize in relation to their compositional variability, taking into account the main parameters implied in their toxicity: namely, $\mathrm{pH}$, electrical conductivity and phenolics. Besides, we investigated the impact of olive mill wastewater fertilisation on maize, considering progressive amendment as well as foliar spray as alternatives to overcome its potential toxicity.

First, the physicochemical characterisation of OMW samples collected in the Marrakech region (Morocco) shows that the five samples were slightly acidic $(\mathrm{pH}=4.63-4.88)$. Soluble phenolics' levels were variable among samples and ranged from $2.96 \pm 0.04 \mathrm{~g} \mathrm{~L}^{-1}$ in $\mathrm{S} 2$ to $6.09 \pm 0.18 \mathrm{~g} \mathrm{~L}^{-1}$ in $\mathrm{S} 4$. Widely variable levels of electrical conductivity were revealed among samples. In particular, olive mill wastewaters from the semi-modern mill (S2) exerted the lowest salinity (11.24 \pm $\left.0.17 \mathrm{mS} \mathrm{cm}^{-1}\right)$; whereas those collected in Loudaya's mill (S3) reached $83.3 \pm 0.20 \mathrm{mS} \mathrm{cm}^{-1}$ (Tab. I). Both salinity and phenolics are recognised to affect plant metabolism deeply, notably in a concentration-dependent way (An et al., 2001). Such a difference in these parameters may explain, at least partially, olive mill wastewater effects' variability.

Besides, the tested olive mill wastewater samples (S1, S2, S3, S4 and S5) show wide variability in terms of their phenolic contents, with a higher diversity in the abundance of some phenolic compounds (Tab. II and Fig. 1). Among the tested samples, the one collected in Loudaya (S3) was the most variable, especially with the presence of caffeic acid and $p$-coumaric acid, whereas the particularity of S1 was obviously the ab- sence of tyrosol and the presence of catechol in a high amount ( $1376.66 \mathrm{mg}$ eq. catechol $\mathrm{L}^{-1}$ ). Noticeably, the greatest difference between the studied samples was observed for catechol, which ranges between $216.29 \mathrm{mg}$ eq. catechol $\mathrm{L}^{-1}$ in the olive mill wastewaters collected in a semi-modern mill (S2) and $1376.66 \mathrm{mg}$ eq. catechol $\mathrm{L}^{-1}$ in S1 (Tab. II). Furthermore, it was possible to notice that several compounds, such as a hydroxycinnamic derivative (peak number 11), luteolin and an unidentified flavonoid (peak number 7), were present in traces or quasi-absent in most samples (Tab. II).

This diversity in olive mill wastewaters' phenolic composition, mainly due to variation in cultivars, maturation stages and the milling process, also contributes to their differential toxicity levels when used in agricultural systems. Actually, phytotoxic effects are attributed to many phenolics in relation to chlorophyll metabolism (Yang et al., 2002), phytohormone metabolism (Aliotta et al., 2000), growth inhibition (Krogmeier and Bremne, 1989) and morphological alterations (Chon et al., 2002). Moreover, phenolic compounds exhibit variable phytotoxicity levels according to their structure and their concentration (An et al., 2001). It has also been shown that phenolic phytotoxicity is variable according to their lipophilicity, probably due to their aptitude to cross biological membranes (Wang et al., 2001).

\subsection{Laboratory phytotoxicity assessment}

The results highlighted a relative tolerance of maize germination to olive mill wastewaters. In fact, at $12.5 \%(\% \mathrm{v})$, olive mill wastewaters did not greatly affect the germination rate in maize or the time of germination (data not shown). On the other hand, effects of olive mill wastewaters were the 


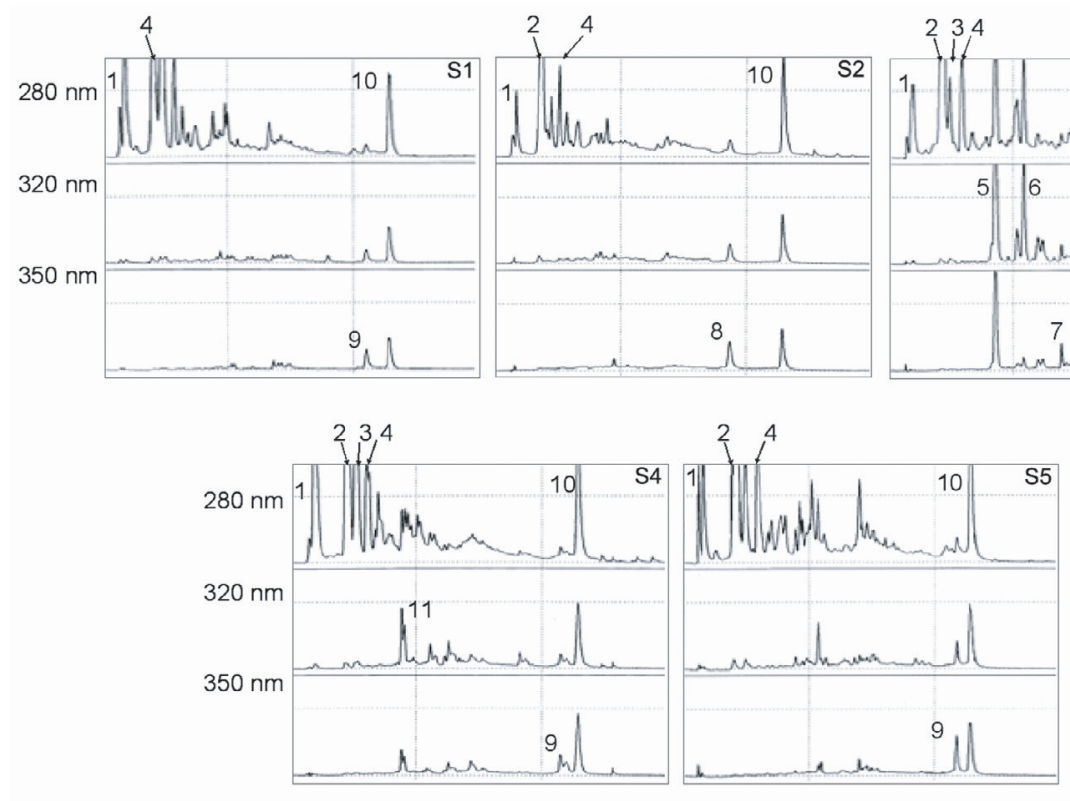

Figure 1. Main phenolics in olive mill wastewater samples: S1, S2, S3, S4 and S5. 1: not identified, 2: Tyrosol, 3: not identified, 4: Catechol, 5: Caffeic acid, 6: p-coumaric acid, 7: Unidentified flavonoid, 8: Luteolin, 9: Luteolin derivative, 10: Oleuropein derivative, 11: Unidentified hydroxycinnamic derivative.

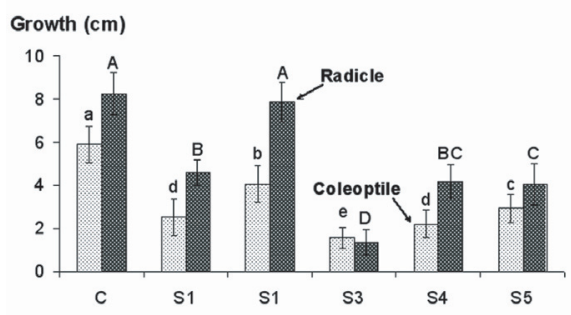

Figure 2. Radicle and coleoptile growth as estimated after 5 days in the presence of olive mill wastewater samples (S1, S2, S3, S4 and S5) as compared with control grown with distilled water (C). The figure shows more relevant inhibition of growth by olive mill wastewater samples with the highest salinity and phenolic content. Sample S2 from a semi-modern mill, and with the lowest electrical conductivity and phenolic content, was the least phytotoxic toward maize seedlings. (Different letters above the bars indicate significant differences at $P<0.05)$.

most perceptible with regard to the first development stages. Thus, coleoptile elongation showed an inhibition ranging from $32 \%$ to $74 \%$, whereas radicle growth inhibition reached $84 \%$ (Figs. 2 and 3). Such a result is in concordance with the general trend demonstrating that germination is less sensitive than seedling growth (Miller, 1996). Relationships of changes in seedling growth with olive mill wastewaters' selected characteristics were determined for each parameter. Coleoptile and radicle elongation, as well as biomass production, were negatively correlated to olive mill wastewater salinity and total phenolics, especially some compounds such as catechol (data

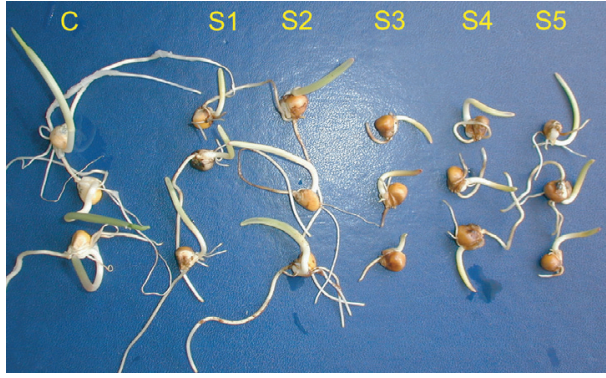

Figure 3. Maize seedling growth after 5 days in the presence of olive mill wastewater samples (S1, S2, S3, S4 and S5) as compared with control grown with distilled water $(\mathrm{C})$. The figure shows more relevant inhibition of growth by olive mill wastewater samples with the highest salinity and phenolic content. Sample S2 from a semi-modern mill, and with the lowest electrical conductivity and phenolic content, was the least phytotoxic toward maize seedlings.

not shown). In fact, several authors attribute OMW toxicity to their phenolic compounds (Capasso et al., 1992; Aliotta et al., 2000). It was described that phenolic compounds such as $p$-coumaric acid and ferulic acid present phytotoxic effects toward plants, consisting of the disturbance of their physiological processes (Aliotta et al., 2000; Yang et al., 2002). Besides, catechol is recognised to possess high phytotoxic potential even at low concentration (An et al., 2001). Salinity is also known for its toxicity due to both the direct effects of $\mathrm{Na}^{+}$and $\mathrm{Cl}^{-}$ions and to their osmotic effect (Mahajan and Tuteja, 2005; Parida and Das, 2005). These findings reveal that the agronomical impact of olive mill wastewaters is related to 


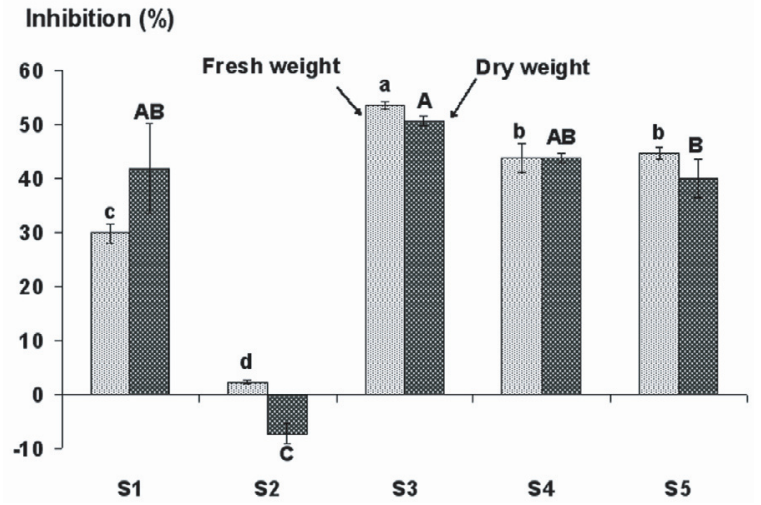

Figure 4. Effects of the tested olive mill wastewater samples (S1, S2, S3, S4 and S5) on total biomass production as compared with control grown with distilled water. The figure shows more relevant inhibition of biomass production by olive mill wastewater samples with the highest salinity and phenolic content. Sample S2 from a semimodern mill, and with the lowest salinity and phenolic content, was the least phytotoxic toward maize seedlings. Indeed, a significant improvement in total dry weight production was obtained by this sample. (Different letters above the bars indicate significant difference at $P<0.05)$.

their compositional variability. However, taking into account the synergistic effect of these constituents, notably phenolics (An et al., 2001), further studies are needed to disclose the contribution of each component in order to manage these effluents better.

On the other hand, the evaluation of total biomass production showed that besides an inhibition by S1, S3, S4 and S5 OMW samples that varied between 30 and 54\% and between 40 and $52 \%$ for fresh weight and dry weight, respectively, a stimulation of 7\% dry weight was recorded using S2 (Fig. 4). Fresh weight measurement is shown to be a less sensitive parameter to stress (Mahhou et al., 2006). Due to their salinity, olive mill wastewaters could be associated with water deficiency, which could lead to insufficient water uptake by seedlings (Mahhou et al., 2006). Besides, taking into account the semi-modern origin of S2, it can be suggested that the level of dilution of toxic compound levels reduces olive mill wastewater toxicity and makes beneficial effects more perceptible. This is in agreement with other results showing the diminution of olive mill wastewater toxicity when diluted (Casa et al., 2003; D'Annibale et al., 2004). Stimulator effects of small doses of toxic chemicals, notably phenolics, can also be suggested. Although such effects are less documented than the inhibitory ones, stimulator effects were reported for some allelochemicals, notably phenolics at low doses (Mandal, 2001; Tefera, 2002; An et al., 2001). Such effects will be of great interest for the optimisation of olive mill wastewater fertilisation. Further analysis of the physiological effects implicated would elucidate the basis of this dual effect of olive mill wastewaters.

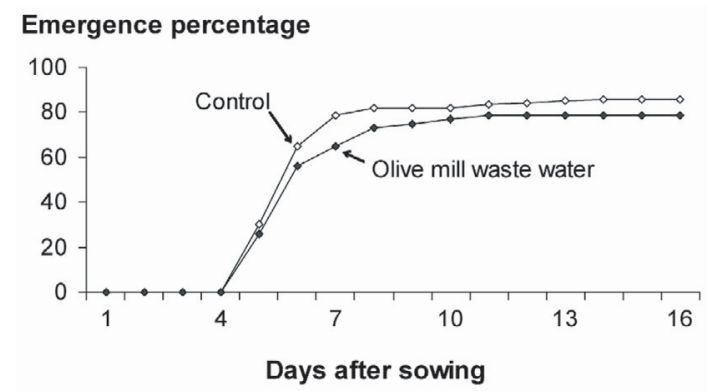

Figure 5. Emergence rate of maize seedlings in olive mill wastewaterpre-treated soil as compared with the control. The figure shows a reduction of seedling emergence due to olive mill wastewater pretreatment.

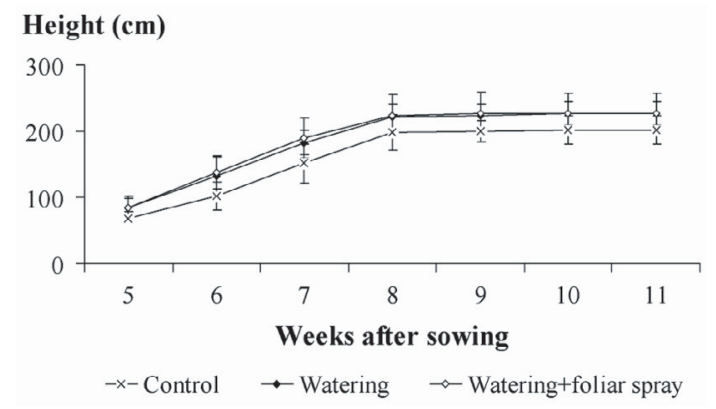

Figure 6. Field growth of olive mill wastewater-fertilised maize as compared with the control. The figure shows similar enhancement of plant height by both olive mill wastewater land application alone and accompanied by foliar spray.

\subsection{Field assays}

When a maize crop was grown in field conditions, a 9\% decrease in seedling emergence was observed in pre-treated soil (Fig. 5). According to laboratory tests, it is highly likely that the observed emergence inhibition was attributed to injuries at the first development stages rather than to germination damage. On the other hand, no negative effect was observed with regard to the latest growth stages of the maize crop. However, field growth was significantly promoted by olive mill wastewater application and reached $10-11 \%$ of the growth of the control at the end of the experiment (Fig. 6).

The apparently contrasting outcomes of the laboratory and field experiments mean that olive mill wastewater toxicity can be counteracted by other beneficial effects on mature plants. This could be due to nutrient availability, notably nitrogen (Nevens and Reheul, 2003; Gavalda et al., 2005), and soil microbial activity stimulation (Tomati et al., 1996), as well as the amelioration of the physical properties of the soil (Fischler et al., 1999). Such results were observed for maize in response to other plant extracts. Indeed, the negative effects observed in laboratory assays were not detected under field conditions since pots and field growth were especially contributary to nitrogen availability (Kamara et al., 2000). It can also be suggested that some of the olive mill wastewaters' 
Table III. Maize yield as estimated by kernel weight and one-hundred-seed weight. Different letters within the same column mean no significant difference at $P<0.05$.

\begin{tabular}{lll}
\hline & Kernel weight $(\mathrm{g})$ & $100-$ Seed-weight $(\mathrm{g})$ \\
\hline Control & $98.5 \pm 21.8^{\mathrm{a}}$ & $18.8 \pm 0.3^{\mathrm{c}}$ \\
Soil application & $97.4 \pm 21.0^{\mathrm{a}}$ & $21.9 \pm 0.3^{\mathrm{b}}$ \\
Soil application + foliar spray & $105.3 \pm 21.2^{\mathrm{a}}$ & $24.1 \pm 1.0^{\mathrm{a}}$ \\
\hline
\end{tabular}

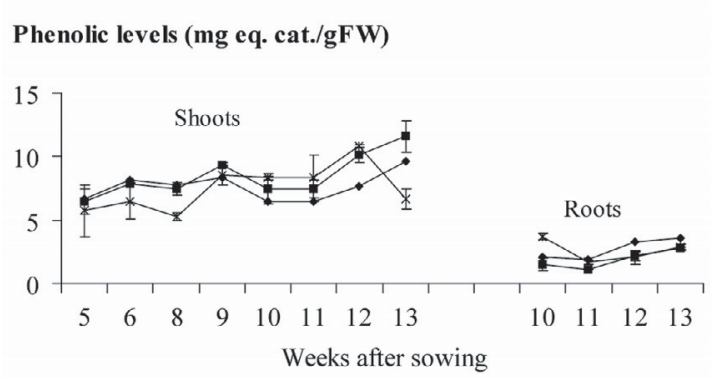

Peroxidasic activity $(\mathrm{EU} / \mathrm{s} / \mathrm{gFW})$

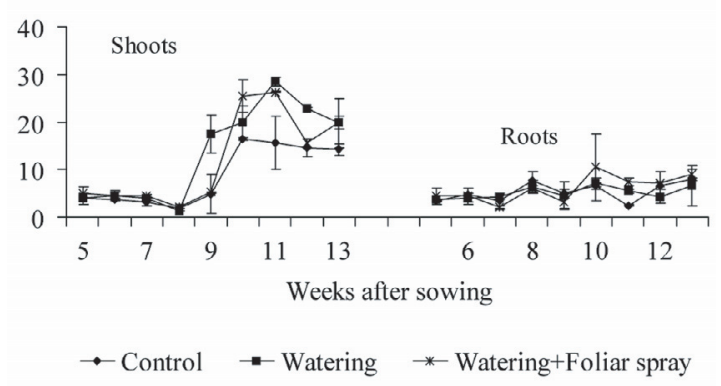

Figure 7. Phenolic and peroxidase activity levels' time course during olive mill wastewater fertilisation.

toxic compounds were inactivated by soil biotic and abiotic components in a field situation. In this sense, Krogmeier and Bremne (1989) showed that phenolic acids, notably caffeic acid and $p$-coumaric acid, affected germination and seedling growth on germination paper of several crops, but did not have any effect on seed germination, seedling growth, or early plant growth in soil, even at higher amounts. This hypothesis is in perfect concordance with phenolic and peroxidase activity results. In fact, in our experiments considering soil amendment with $30 \mathrm{~m}^{3} \mathrm{ha}^{-1}$ of olive mill wastewaters, the evaluation of phenolic amounts and peroxidase levels as well as phenolic profiles showed no physiological damage to be credited to olive mill wastewater fertilisation (Fig. 7). Taking into account our previous results where phenolics and peroxidases were demonstrated to be sensitive parameters indicating olive mill wastewater toxicity towards several crops, notably maize (El Hadrami et al., 2004), it can be concluded that this fractionated fertilisation method can be considered safe since it allows biological degradation of toxic compounds and reduces the apparent phytotoxicity.
Concerning yield, a net amelioration in seed weight was observed. This can be attributed to the improvement in seed filling due to nutrient availability (Nevens and Reheul, 2003; Gavalda et al., 2005). The most noticeable improvement was obtained particularly when watering was accompanied by foliar spray. Thus, one-hundred-seed weight was increased by $28 \%$ while root application alone resulted in an augmentation of $16 \%$ (Tab. III). This can be explained by the compensation of insufficient uptake by maize roots as opposed to foliar application of NPK fertilisation (Ling and Silberbush, 2002). To our knowledge, except for the foliar application of the by-product of a two-step olive mill (Tejada and Gonzalez, 2003), this is the first report on foliar spray of olive mill wastewaters from a three-step process. It is pertinent to note this added value of olive mill wastewater foliar spray as a low-cost fertiliser that could be used to avoid potential hazards toward soils.

\section{CONCLUSION}

Relevant variability was revealed among the tested olive mill wastewater samples, particularly with regard to their phenolic composition, resulting in variability in their phytotoxicity level. In field conditions, a $9 \%$ reduction of seedling emergence in pre-treated soil was observed as compared with the control. This data shows the sensitivity of preliminary development stages to olive mill wastewaters. However, a net improvement in the growth of 10 to $11 \%$ was obtained, respectively, when olive mill wastewaters were applied as soil amendment or as a combination of soil and foliar fertilisation. A yield improvement was also observed and reached $28 \%$ when plants were amended both by root watering and foliar spray as compared with $16.5 \%$ for the sole land amendment. These results show that the large variability in olive mill wastewater composition constitutes the major limiting factor to generalising their safe use in agriculture. However, olive mill wastewaters can be safely used as amendment provided the application is moderate and progressive and critical crop developmental stages are avoided. Foliar fertilisation using olive mill wastewaters is also a promising way to reduce ecological damage and optimise olive mill wastewater recycling. Further studies concerning olive mill wastewater toxicity evolution during storage and residual effects on the soil's intrinsic buffering capacity are required to go deeper into a suitable and sustainable agricultural practice without any treatment of olive mill wastewaters.

Acknowledgements: The financial support provided by EC contract No. ICA3-CT-2002-10033 is gratefully acknowledged. 


\section{REFERENCES}

Aliotta G., Cafiero G., De Feo V., Di Blasio B., Iacovino R., Oliva A. (2000) Allelochemicals from Rue (Ruta graveolens L.) and Olive (Olea europea L.) oil mill waste as potential natural pesticides, Curr. Top. Phytochem. 3, 167-177.

An M., Pratley J.E., Haig T. (2001) Phytotoxicity of Vulpia Residues: III. Biological Activity of Identified Allelochemicals from Vulpia myuros, J. Chem. Ecol. 27, 383-394.

Ben Rouina B., Taamallah H., Ammar E. (1999) Vegetation water used as a fertilizer on young olive plants, Acta Hort. 474, 353-355.

Capasso R., Cristinzio G., Evidente A., Scognamiglio F. (1992) Isolation spectroscopy and selective phytotoxic effects of polyphenols from vegetable waste waters, Phytochemistry 31, 4125-4128.

Casa R., D’Annibale A., Pieruccetti F., Stazi S.R., Giovannozzi Sermanni G., Lo Cascio B. (2003) Reduction of the phenolic components in olive-mill wastewater by an enzymatic treatment and its impact on durum wheat (Triticum durum Desf.) germinability, Chemosphere $50,959-966$.

Chon S.U., Choi S.K., Jung S., Jang H.G., Pyo S., Kim S.M. (2002) Effects of alfalfa leaf extracts and phenolic allelochemicals on early seedling growth and root morphology of alfalfa and barnyard grass, Crop Protect. 21, 1077-1082.

D’Annibale A., Casa R., Pieruccetti F., Ricci M., Marabottini R. (2004) Lentinula edodes removes phenols from olive-mill wasrewater: impact on durum wheat (Triticum durum Desf.) germinability, Chemosphere 54, 887-894.

Eghball B., Ginting D., Gilley J.E. (2004) Residual Effects of Manure and Compost Applications on Corn Production and Soil Properties, Agron. J. 96, 442-447.

El Hadrami A., Belaqziz M., El Hassni M., Hanifi S., Abbad A., Capasso R., Gianfreda L., El Hadrami I. (2004) Physico-chemical Characterization and Effects of Olive Oil Mill Wastewaters Fertirrigation on the Growth of Some Mediterranean Crops, J. Agron. 3, 247-254.

Fischler M., Wortmann C.S., Feil B. (1999) Crotalaria (C. ochroleuca G. Don.) as a green manure in maize-bean cropping systems in Uganda, Field Crop. Res. 61, 97-107.

Gavalda D., Scheiner J.D., Revela J.C., Merlina G., Kaemmerer M., Pinelli E., Guiresse M. (2005) Agronomic and environmental impacts of a single application of heat-dried sludge on an Alfisol, Sci. Total Environ. 343, 97-109.

Kamara A.Y., Akobundu I.O., Sanginga N., Jutzi S.C. (2000) Effect of mulch from selected multipurpose trees (MPTs) on growth, nitrogen nutrition and yield of maize (Zea mays L.), J. Agron. Crop Sci. $184,73-80$.

Krogmeier M.J., Bremner J.M. (1989) Effects of phenolic acids on seed germination and seedling growth in soil, Biol. Fert. Soils 8, 116122.
Ling F., Silberbush M. (2002) Response of maize to foliar vs. soil application of nitrogen-phosphorus-potassium fertilizers, J. Plant Nutr. $25,2333-2342$.

Mahajan S., Tuteja N. (2005) Cold, salinity and drought stresses: An overview, Arch. Biochem. Biophys. 444, 139-158.

Mahhou A., DeJong T.M., Shakel K.S., Cao T. (2006) Water stress and crop load effects on yield and fruit quality of Elegant Lady Peach [Prunus persica (L.) Batch], Fruits 61, 407-418.

Mandal S. (2001) Allelopathic activity of root exudates from Leonurus sibiricus L. (Raktodrone), Weed Biol. Manage. 1, 170-175.

Mekki A., Dhouib A., Aloui A., Sayadi S. (2006) Olive wastewater as an ecological fertiliser, Agron. Sustain. Dev. 26, 61-67.

Mellouli H. J., Hartmann R., Gabriels D., Cornelis W.M. (1998) The use of olive mill effuents ("margines") as soil conditioner mulch to reduce evaporation losses, Soil Till. Res. 49, 85-91.

Miller D.A. (1996) Allelopathy in forage crop systems, Agron. J. 88, $854-859$

Nevens F., Reheul D. (2003) The application of vegetable, fruit and garden waste (VFG) compost in addition to cattle slurry in a silage maize monoculture: nitrogen availability and use, Eur. J. Agron. 19, 189-203.

Parida A.K., Das A.B. (2005) Salt tolerance and salinity effects on plants: a review, Ecotox. Environ. Safe. 60, 324-349.

Piotrowska A., Iamarino G., Rao M.A., Gianfreda L. (2006) Short-term effects of olive mill waste water (OMW) on chemical and biochemical properties of a semiarid Mediterranean soil, Soil Biol. Biochem. $38,600-610$.

Rashid M.T., Voroney R.P. (2004) Land Application of Oily Food Waste and Corn Production on Amended Soils, Agron. J. 96, 997-1004.

Tefera T. (2002) Allelopathic Effects of Parthenium hysterophorus extracts on Seed Germination and Seedling Growth of Eragrostis tef, J. Agron. Crop Sci. 188, 306-310.

Tejada M., Gonzalez J.L. (2003) Effects of foliar application of a byproduct of the two-step olive oil mill process on maize yield, Agronomie 23, 617-623.

Tomati U., Galli E., Fiorelli F., Pasetti L. (1996) Fertilizers from composting of olive-mill wastewaters, Int. Biodegr. Biodeter. 38, 155-162.

Wang X., Sun C., Gao S., Wang L., Shuokui H. (2001) Validation of germination rate and root elongation as indicator to assess phytotoxicity with Cucumis sativus, Chemosphere 44, 1711-1721.

Yang C.M., Lee C.N., Chou C.H. (2002) Effects of three allelopathic phenolics on chlorophyll accumulation of rice (Oryza sativa) seedlings: I. Inhibition of supply-orientation, Bot. Bull. Acad. Sinica 43, 299304.

Zenjari B., Nejmeddine A. (2001) Impact of spreading olive mill wastewater on soil characteristics: laboratory experiments, Agronomie 21, 749-755. 